\section{ECONOMICS}

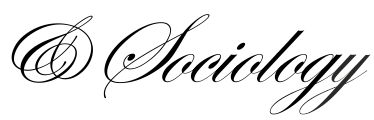

Kot, S., Goldbach, I. R., \& Ślusarczyk, B. (2018). Supply chain management in SMEs - Polish and Romanian approach. Economics and Sociology, 11(4), 142-156. doi:10.14254/2071-789X.2018/11-4/9

\title{
SUPPLY CHAIN MANAGEMENT IN SMES - POLISH AND ROMANIAN APPROACH
}

\author{
Sebastian Kot, \\ WSB University, \\ Dabrowa Górnicza, Poland \\ North-West University, \\ Vaal Triangle, South Africa \\ E-mail:sebacat@pocrta.mp.pl \\ Ioana Raluca Goldbach, \\ Nicolae Bălcescu Land Forces \\ Academy, \\ Sibiu, Romania, \\ E-mail:ioanagoldbach@yahoo.com \\ Beata Ślusarczyk, \\ Czestochowa University of \\ Technology, Crestochowa, Poland \\ North-West University, Vaal \\ Triangle, South Africa \\ E-mail: \\ beata.slusarcsyk@wz:pcz:pl
}

Received: May, 2018

1st Revision: June, 2018

Accepted: October, 2018

DOI: $10.14254 / 2071-$

789X.2018/11-4/9

JEL Classification: D85, L14

\begin{abstract}
The concept of supply chain management is a ubiquitous subject in both theoretical and practical analyses. Studies on the implementation of Supply Chain Management by Small and Medium Enterprises are relatively rare and their scope is limited to selected aspects. Hence, the aim of this article is to analyze the implementation of Supply Chain Management concept by Small and Medium-sized Enterprises. The research sample consists of Small and Medium Enterprises of Poland and Romania. The research tool was a survey questionnaire, which was divided into the part identifying the respondents and the substantive part concerning Supply Chain Management (SCM). Likert's five-level scale was used to evaluate the SCM concept application in small and medium entities, which measured the average level of the evaluation of factors in various SCM areas. The results of the study show similar involvement in the implementation of the concept, although there are significant differences in the selected areas, such as cost reduction and concentration on end customers. The research carried out in this paper has evaluated the SCM concept in SMEs measuring the average level in an evaluation of factors concerning different SCM areas. They are identified on the basis similarities and differences in the approach to SCM concept in Polish and Romanian enterprises.
\end{abstract}

Keywords: Supply Chain Management, Small and Medium Enterprises, Poland, Romania, Survey.

\section{Introduction}

Small and Medium Enterprises are the key to the process of shaping economic growth at both domestic and international levels (Korcsmáros \& Šimova, 2018; OECD, 2009). In today's complex and highly competitive business environment, adopting appropriate strategies is particularly important for SMEs' efforts to survive (Abrhámet al., 2015; Zygmunt, 2018; Kozubikova et al., 2017; Kljucnikov et al., 2016; Ahmad et al., 2018). In this context, application of the concept of Supply Chain Management (SCM) in the strategies of SMEs seems to be very important since the supply chain operation covers all actions and activities associated with the flow and transformation of products from raw materials through various 
processes to the end customer. Of course, along with the flow of goods in a supply chain, all necessary and related information is also on the move. Competition is rapidly moving from the level of the enterprise to the level of supply chains. Nowadays, customers expect companies to supply better and cheaper products to provide faster and more flexible shipments, as well as other services with a higher level of quality (Kozma, 2017; Zimon, 2017; Kovács and Kot, 2016; Liberko et al., 2015). Therefore, it is essential to study the problems of SCM implementation by Small and Medium Enterprises, especially considering the fact that this topic is not so well described in the literature so far.

\section{Literature review}

A review of world literature in the context of Supply Chain Management indicates a significant disparity in the number of studies for Small and Medium Enterprises. There are no comprehensive and cross-sectional studies in this area and the authors focus on small research samples, based on the fragmented nature of research. A significant part of research on Supply Chain Management is about the relationship between SMEs sector and their performance in the analyzed countries. It has been shown that the lack of effective implementation of Supply Chain Management in SME sectors by using technology and systems results in a loss of competitiveness and the focus on strategic supply chain performance can improve SMEs sector operations efficiently to achieve the competitive advantage (Androniceanu, 2017). Arend and Wisner point out that Supply Chain Management is not suitable for SME sectors (Arend and Wisner, 2005), and in practice, it leads to not as good as business performance and less return on investment.

The studies of Thakkar et al. (2008); Thakkar et al. (2011); Ehrenberger et al. (2015); Tvaronavičienè (2015), Kot (2018); Oláh et al. (2017); Nze, I., \& Onyemechi, C. (2018); Onwuegbuchunam, D., Okeke, K., Igboanusi, C., \& Ugboma, O. (2018) connect with this subject and note that some SMEs see the benefits of supply chain management activities such as collaboration leading to a focus on activities bringing value, more transparent development of strategy and cooperation of supply chain members in the area of improving competitiveness. However, still, a part of SMEs sector perceives Supply Chain Management as a tool to achieve customers' satisfaction through significant investments in information technologies.

Issues related to the sector of Small and Medium Enterprises are also a subject of interest willingly raised by the researchers of Poland. The topic of Supply Chain Management is trendy in recent years, and SCM is the subject of an ever-increasing number of scientific publications. However, the combination of these two issues i.e. the role of Small and Medium Enterprises in the Supply Chains and chain management from the perspective of such entities is the area of knowledge inadequately explored by Polish researchers. Even though the authors of the previous studies use the terms like supply chain and small and medium businesses in their titles, the actual intentions of the studies are not related to supply chain or small and medium businesses. Consequently, in these studies, there are no references to the actions of small and medium enterprises in the supply chains. The role of Small and Medium Enterprises as supply chain links is also recognized by K. Zowada (2011), who emphasizes that these entities can link the chain effectively. He believes that due to its features such as flexibility, ability to adapt to customers' requirements, adaptability to changes in the environment and lower plant costs SMEs can achieve strong positions in the chains, though in most cases it will not be the role of the leader of the whole chain. A complete study related to supply chain management from the point of view of small and medium enterprises was published in 2010, entitled "The functioning of small and medium manufacturing companies 
in the supply chain" (Kisperska-Moron et al., 2010). It reflects the various spheres and functions of Small and Medium Enterprises in the supply chain.

In 2017, O. Dumitrescu and C. M. Hila published their research work, entitled "Actual state of knowledge in the field of Supply Chain Management". The study of this paper describes the second part of their bibliographic research in SCM and analyses the actual state of the scientific knowledge in the field of Supply Chain Management and to ascertain the eventual gaps of knowledge in this area, and it has also identified the potentially unexplored research directions. The authors consider that for the development of the specialty literature in the field of Supply Chain Management, performance evaluation can be achieved by developing Key Performance Indicators (KPI) with influence on the supply chain. In the current business environment, M. Ghicajanu (2014) considers that the performance criteria related to SCM are the value brought to customer, quality, service and speed; and one must seek solutions and business models that meet these criteria at the best levels. In this sense, SCM must be opened always for innovative solutions, changes in some fields, redesigning programs (Shpak et al., 2017; Szczepańska-Woszczyna, 2014). The author considers that one such approach would be the open innovation program, the direction in which the article supplies a case study from Procter \& Gamble. C. Vasiliu and M. Dobrea (2013) appreciated that the issue of SCM is the interest of companies in Romania. Although the stage of development is low and the integration of all activities is under evaluated. That is because they observed that the companies are predominantly oriented inwards and the networking, use of 3PL providers, interfaces are weak. The exploratory research was conducted as a selective survey to define SCM state of implementation in Romania over 225 questionnaires, with authors' comment that the sample is not representative for Romanian economy.

D. M. Diaconu and C. Alpopi (2014) conducted a study over the strengths and weaknesses of current SCM in Romania, at different levels: strategic orientation, process and IT support management and organization, cooperation and measurements. Despite many events that have happened since the study was initiated, the authors observed that service level increased, but stock level has not decreased as previewed as one of the key components of logistic cost. To conclude, it is identified that there is an improvement in communication between the internal departments and also with external suppliers. Simultaneously, companies focusing on SCM can obtain a competitive advantage by lowering costs and improving customer satisfaction. ERP software has gained popularity especially among medium and large enterprises in Romania R. I. Țarţavulea and R. I. Petrariu (2013). The study not only deals with logistics market statistics but also it identifies the software platform to the SMEs of Romania. It is noted that the financial and accounting departments are benefited by an ERP solution and support ERP solution in a proportion of $77.2 \%$ of the companies interviewed. Only $19.9 \%$ of companies have chosen to purchase all available modules or an ERP system as a whole. In terms of the supply chain management, the companies in Romania, according to studies cited in the paper, managers give a medium importance to the SCM process. The logistics sector represents about 10\% of Romania's GDP and estimates by specialists suggest that this percentage could increase in the future.

O. Kherbach and M. L. Mocan (2015) consider that in terms of resources (financial, technological and human), SMEs are disadvantaged when compared with large firms, considering that organizational and behavioural flexibility is a significant asset to compete for the virtual market. IT is a powerful technology in SCM for SMEs. IT increases SMEs performance by boosting up the efficiency in the supply and production such as centreproduct and customer centre. To conclude, Romanian SMEs needs to develop and implement SCM systems that continuously integrate all organizations and provide resources to customer centers to maintain the existence in the regional, national and international markets. In 2016, Oracle made a survey in five regions based on IDG Connect, the regions are North America, 
Europe, the Middle East and Africa (EMEA), Central and South America, and Asia - Pacific and it aims to discover the attitudes and plans towards adopting the cloud-based Supply Chain Management (SCM) solutions. The top three strategic advantages of SCM were considered notably, 66\% Operational efficiencies, 61\% Productivity improvements, and $60 \%$ Cost savings. The Cloud-based SCM advantages were identified by $61 \%$ faster implementation, $60 \%$ cost savings and 59\% improved customer service. Another study over logistics and SCM for the development of Romanian SMEs was conducted by O. Kherbach and M. L. Mocan (2016). The study investigates how logistics can be considered as a tool for developing the activity of Romanian's SMEs to drive a proper organization of the business and create a business edge. The authors have concluded that success in assimilating worldwide supply chains starts with the ability of companies to move goods across borders, consistently and inexpensively. In order to connect the Romanian economy to the world trends and processes, the highest priority should be given to the improvement of logistics and SCM in Romania, SMEs with well-organized logistics and SCM will be able to take full advantage of their abundance and develop their competitiveness.

The position of the Romanian SMEs regarding the SCM is not comparable with the big companies. Considering that SMEs dominate in the Romanian economy, authors conclud that the development of the Romanian economy is based on the development of the Romanian SMEs. From an SCM strategy point of view, R. Wright's (2013) study shows that there is a link between supply chain strategy and product type and The Alignment Effect on performance is inconclusive. The assessment of supply chain strategy and product type, as well as a role in the supply chain, is challenging. Even though a systematic approach is used, it is difficult to evaluate these aspects based on secondary data. The factors determining supply chain strategy indicate that manufacturing companies in Romania align their strategy from the type of product. The study has concluded that flexibility and adaptability are critical due to the complexities of SCM in Romania. From a financial point of view, a study over a new solution for SCM resilience, in Romanian companies, by V. Popa (2013) shows that reverse factoring does not solve all liquidity issues when credit is stretched. But, it is recommended for reducing working capital in the long term. The study suggests three steps such as clarification of organizational responsibilities, strategy framework implementation, and pilot testing. Those are suggested to be key concepts in defining upstream propose to work using a generic process model to illustrate the entire supply chain, including 4PL and at another level, the study has considered 3PL type organizations. Another problem is that the study also discusses the situations in crisis and it recommends the rescheduling of invoice payments and an alliance between the two organizations. The study collaborates with above mentioned ones in regards to appreciating that the collaborative management approach SCM must be extended from the physical exchange of prime materials.

Despite many cited studies about Supply Chain Management in the SMEs sector, there is an inadequate knowledge on the relationship between supply chain management and the functioning of companies of the SMEs sector. This identified gap seems to be an essential issue for researchers and management practitioners. The analysis of the factors supporting and hampering the implementation of Supply Chain Management in large enterprises and companies of the SMEs sector is also equally important. As yet, studies showing whether companies in the SMEs sector can implement Supply Chain Management at large companies, in which case it has been successful, are insufficient. The purpose of the research is to assess the function of Supply Chain Management in Small and Medium Enterprises of Romania and Poland, and more specifically to identify the similarities and differences of SCM concept in selected countries. 


\section{Methodological approach}

The questionnaire has been developed by the authors to collect all necessary data related to the practice of SCM in Small and Medium Enterprises (SMEs). The questionnaire has been divided into two; the part identifying the respondents and the substantive part concerning Supply Chain Management (SCM). Likert's five-level scale is used to evaluate the SCM concept in Small and Medium Enterprises. Table 1 describes the average measured level of evaluated factors in the SCM areas. Polish and Romanian Small and Medium Enterprises are randomly sampled with the national statistics offices data serving as the base of the draw. The draw has dependent unrestricted characteristics. The data was collected through the direct method between June and November 2017, and the same sample size (211 SMEs) is collected from the surveyed country. The obtained research sample for this study has corresponded to the materiality level $p=0.1$ at the maximum admissible error of 0.05 . It needs to be noted that some of the respondents did not answer all of the questions. Hence, there are a significant number of rejected surveys, and the sample structure is chosen randomly.

Table 1. Independent and Dependent Variables in the Survey

\begin{tabular}{|c|c|}
\hline Independent variables & Dependent variables \\
\hline Country & SCM determinants \\
\hline Size of entity & Factors supporting SCM \\
\hline $\begin{array}{l}\text { Time of operation of the company on the } \\
\text { market }\end{array}$ & Barriers in the implementation of SCM \\
\hline Industry & Sort of practices \\
\hline \multirow{3}{*}{ Position } & Functioning of the company within the supply chain \\
\hline & Environmental elements of the sustainable development \\
\hline & Social elements of the sustainable development \\
\hline
\end{tabular}

Source: own compilation

The majority of the surveyed Polish companies are small entities. In Romania, the division between small and medium businesses is almost identical (Table 2). It is identified from the fact that there is no correlation between the size of the subject and the evaluation of elements of SCM concept, and it is assumed that the difference between the structures of the two countries will not influence the results of further analysis.

Table 2. Structure of the Sample based on Employment Size

\begin{tabular}{lcc}
\hline Employment & Poland & Romania \\
\hline $10-49$ & $76.42 \%$ & $54.6 \%$ \\
\hline $50-249$ & $23.6 \%$ & $45.4 \%$ \\
\hline
\end{tabular}

Source: own compilation

The sample structure is also studied in relation to the time of operation on the market (Table 3).

Table 3. Structure of the Sample based on the Years of Operation on the Market

\begin{tabular}{lcc}
\hline Years of Operation & Poland & Romania \\
\hline up to 3 years & $8.6 \%$ & $13.2 \%$ \\
\hline 3 - 7 years & $22.8 \%$ & $22.8 \%$ \\
\hline 8 - 15 years & $20.8 \%$ & $36.4 \%$ \\
\hline more then15 years & $47.8 \%$ & $27.6 \%$ \\
\hline
\end{tabular}

Source: own compilation 
It is observed that companies operating more than 7 years on the market are dominant in the survey both in Poland and Romania. These companies account for more than $60 \%$ of the surveyed entities. The Romanian surveyed companies carry out their activities most often in the area of logistics and transport, electronics and also in retail and wholesale $(40 \%$ in total). Among Polish companies, there is much greater fragmentation due to the area of functioning of the surveyed entities (Table 4).

Table 4. Classification of Samples based on Branches

\begin{tabular}{ccc}
\hline Branch & Poland & Romania \\
\hline Logistics and transportation & 27 & 37 \\
\hline Cars and automotive parts & 9 & 22 \\
\hline Metal products and machines & 13 & 2 \\
\hline Electronics & 5 & 36 \\
\hline Clothing and textiles & 12 & 17 \\
\hline Services & 6 & 1 \\
\hline Processing of agricultural products and food production & 36 & 30 \\
\hline Furniture manufacturing & 1 & 6 \\
\hline Plastics and chemistry & 10 & 13 \\
\hline Construction and construction products & 11 & 0 \\
\hline Wholesale and retail trade & 6 & 1 \\
\hline Others & 15 & 34 \\
\hline Total & 34 & $\mathbf{2 1 1}$ \\
\hline
\end{tabular}

Source: own compilation

It is clearly observed that in case of Polish companies the questionnaire was filled by the main board. In the case of Romanian companies, the distribution of positions is almost uniform and concerns primarily the position of the director due to the different scope of his duties (Figure 1).

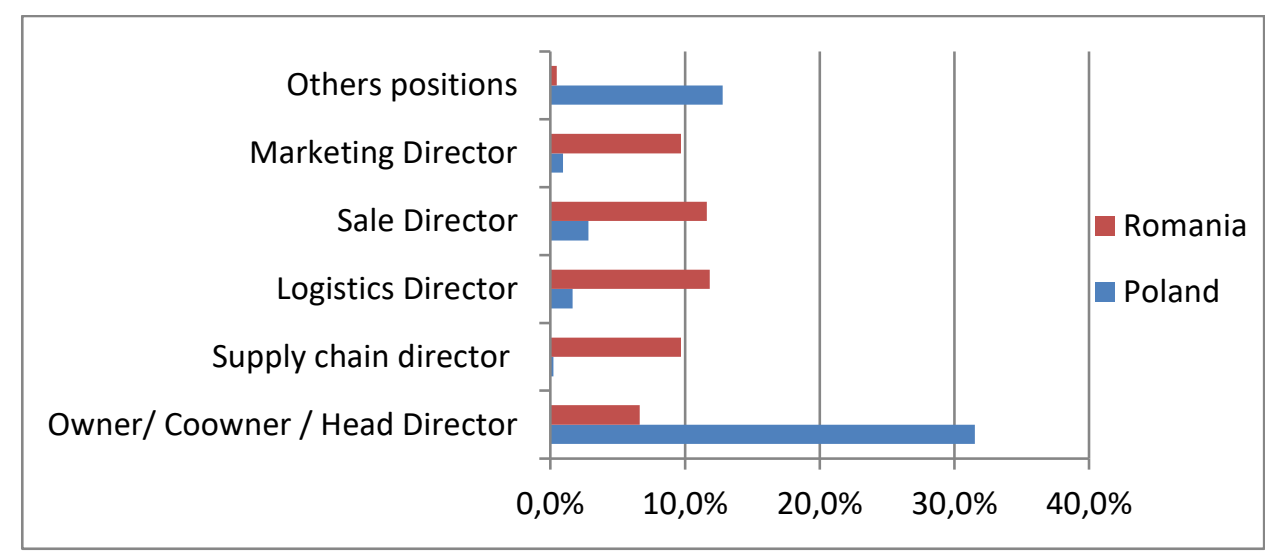

Figure 1. Positions of the Respondents of Studied Enterprises

Source: own data

\section{Evaluation of SCM implementation in SMEs in Poland and Romania}

The main research is the assessment of the approach to Supply Chain Management in the Small and Medium Enterprises of Poland and Romania. The Supply Chain Management's 
determinants are defined as strategic factors for competitive advantage and placed at first. Table 5 presents the average rating of the respondents.

Table 5. SCM determinants

\begin{tabular}{|c|c|c|c|c|}
\hline \multirow[t]{2}{*}{ SCM determinants } & \multicolumn{4}{|c|}{$\begin{array}{c}\text { Average grade (where } 1=\text { doesn't matter, } \\
2=\text { unimportant, } 3=\text { neutral, } 4=\text { important, } \\
5=\text { very important) }\end{array}$} \\
\hline & Poland & St. dev. & Romania & St. dev. \\
\hline $\begin{array}{l}\text { Global competitiveness against our } \\
\text { supply chain }\end{array}$ & 3.5 & 1.06619 & 3.2 & 0.66735 \\
\hline End customer needs & 4.7 & 0.53676 & 4.0 & 0.77033 \\
\hline $\begin{array}{l}\text { Integration of processes within the } \\
\text { supply chain }\end{array}$ & 4.0 & 0.78657 & 4.0 & 0.56753 \\
\hline Members of supply chain cooperation & 4.3 & 0.73740 & 3.8 & 0.74586 \\
\hline Costs reduction & 4.4 & 0.74243 & 3.8 & 0.64405 \\
\hline Improving processes and productivity & 4.3 & 0.75390 & 4.3 & 0.50967 \\
\hline Internal cross-functional cooperation & 4.2 & 0.67328 & 4.5 & 0.68728 \\
\hline
\end{tabular}

Source: own compilation

The average rating indicates that Polish companies are more likely to view the proposed SCM determinants as important. Romanian companies are more concerned about cooperation in the supply chain or cost reduction. At the same time, both Polish and Romanian entities do not take global competition against their supply chain seriously as determinants of the implementation of SCM concept. The most important reason for the application of SCM in SMEs in Poland is for the needs of end customer and in Romania, it is for internal cross-functional cooperation.

Table 6 presents an evaluation of factors supporting the implementation of SCM, according to the definition; these factors are the "elements of the environment of the supply chain, which cause that SCM is easier to implement".

Table 6. Factors Supporting SCM

\begin{tabular}{|c|c|c|c|c|}
\hline \multirow[t]{2}{*}{ Factors Supporting SCM } & \multicolumn{4}{|c|}{$\begin{array}{c}\text { Average grade (where } 1=\text { doesn't matter, } \\
2=\text { unimportant, } 3=\text { neutral, } 4=\text { important, } \\
5=\text { very important) }\end{array}$} \\
\hline & Poland & St. dev. & Romania & St. dev. \\
\hline Information technology & 4.1 & 0.79555 & 4.2 & 0.81081 \\
\hline $\begin{array}{l}\text { The Process of the integration of } \\
\text { processes amongst members of the } \\
\text { supply chain }\end{array}$ & 4.0 & 0.72275 & 4.3 & 0.59680 \\
\hline Concentration on end customers & 4.6 & 0.59381 & 3.9 & 0.48966 \\
\hline $\begin{array}{l}\text { Understanding the concept of SCM and } \\
\text { the support from the managers }\end{array}$ & 4.0 & 0.73023 & 4.4 & 0.49575 \\
\hline $\begin{array}{c}\text { The Organizational structure designed for } \\
\text { the purpose of the promotion of } \\
\text { cooperation and the coordination of } \\
\text { activities }\end{array}$ & 4.0 & 0.72627 & 4.4 & 0.81719 \\
\hline $\begin{array}{l}\text { Trust and openness amongst members of } \\
\text { the supply chain }\end{array}$ & 4.2 & 0.71037 & 4.2 & 0.58754 \\
\hline Readiness to share the knowledge & 4.0 & 0.81245 & 4.1 & 0.68912 \\
\hline
\end{tabular}

Source: own compilation 
In the case of factors supporting the implementation of SCM concept, a more positive approach is observed among Romanian companies, where the average rating is lower while focusing only on the end customers. Inversely, Polish companies rated this factor as the highest. In turn, the most important factors in the SMEs sector in Romania are the understanding of SCM concept and the support has been received in terms of cooperation and coordination from the managers and the organization. Further, barriers in implementing SCM are analyzed. According to the definition, barriers mean "obstacles to SCM application (...) being able to potentially cause failure in putting SCM into practice".

Table 7. Barriers While Implementing the Supply Chain Management

\begin{tabular}{|c|c|c|c|c|}
\hline \multirow[t]{2}{*}{ Barriers of SCM } & \multicolumn{4}{|c|}{$\begin{array}{c}\text { Average grade (where } 1=\text { doesn't matter, } \\
2=\text { unimportant, } 3=\text { neutral, } 4=\text { important, } \\
5=\text { very important) }\end{array}$} \\
\hline & Poland & St. dev. & Romania & St. dev. \\
\hline $\begin{array}{l}\text { Lack of understanding of goals and ideas of } \\
\text { SCM amongst employees }\end{array}$ & 3.8 & 0.83151 & 4.3 & 0.69268 \\
\hline $\begin{array}{l}\text { The Resistance of employees before } \\
\text { implementing changes connected with SCM }\end{array}$ & 3.8 & 0.86880 & 4.4 & 0.73713 \\
\hline $\begin{array}{l}\text { An Organizational structure hampering the } \\
\text { information exchange }\end{array}$ & 4.0 & 0.87158 & 4.0 & 0.66505 \\
\hline $\begin{array}{l}\text { Problems with the quality of activities caused } \\
\text { by members of the supply chain }\end{array}$ & 4.1 & 0.80028 & 4.0 & 0.67472 \\
\hline Communication problems and confidential data & 4.2 & 0.81694 & 4.3 & 0.49643 \\
\hline $\begin{array}{l}\text { Laws and provisions hampering relations in } \\
\text { SCM }\end{array}$ & 4.0 & 0.90227 & 4.6 & 0.70213 \\
\hline $\begin{array}{l}\text { Some members of the supply chain do not } \\
\text { support SCM concept }\end{array}$ & 3.8 & 0.91828 & 4.0 & 0.74334 \\
\hline
\end{tabular}

Source: own compilation

In the case of analysis of barriers of SCM implementation in Poland, the general trend for low evaluations is seen. For Romanian enterprises, the impediments constitute the most important issue of applying the concept. Simultaneously, Polish companies have the communication problems and data privacy handed over to the supply chain as the biggest obstacle, in contrast with Romanian companies, which are more afraid of formal restrictions, and laws and provisions slow down the relations in SCM frames. Further, the degree of implementing practices of Supply Chain Management is examined in the enterprises.

The distribution of average grades of the level of implemented SCM practices indicates that the level of advancement of the SCM concept in Polish companies is usually at the partial implementation stage. Another higher stage of the implementation of selected practices is more likely to be seen in Romanian companies. In Poland, the most advanced is building long-term relationships with the rest members of the supply chain, in line with established guidelines based on long-term contracts and contracts. In Romania, the use of supply chain concept is best developed as a tool for product, process and packaging design.

An important aspect of implementing the SCM concept is also the functioning of the enterprise in relation to the supply chain capabilities based on the requirements of the end customer. Therefore, it is subsequently important to ask about assessing the entity's performance against its main competitors during last year (2016) for each selected indicator (Table 9). 
Table 8. Supply Chain Management practice

\begin{tabular}{|c|c|c|c|c|}
\hline \multirow[t]{2}{*}{ Practices } & \multicolumn{4}{|c|}{$\begin{array}{c}\text { Average grade }(1=\text { no implementation, } \\
2=\text { low level of implementation, } 3=\text { partial } \\
\text { implementation, } 4=\text { implementation, } \\
5=\text { full implementation })\end{array}$} \\
\hline & Poland & st. dev. & Romania & st. dev. \\
\hline $\begin{array}{c}\text { Members of our supply chain jointly manage } \\
\text { inventory and logistics }\end{array}$ & 3.3 & 0.94765 & 4.1 & 0.78903 \\
\hline $\begin{array}{c}\text { Members of our supply chain use information } \\
\text { technologies to increase the efficiency of } \\
\text { communication }\end{array}$ & 3.7 & 0.96129 & 3.5 & 0.45348 \\
\hline $\begin{array}{l}\text { Members of our supply chain build long-term } \\
\text { relationships based on established guidelines }\end{array}$ & 3.9 & 0.90631 & 3.8 & 0.63983 \\
\hline $\begin{array}{l}\text { Members of our supply chain have the clear } \\
\text { vision of Supply Chain Management }\end{array}$ & 3.5 & 0.96216 & 4.2 & 0.62924 \\
\hline $\begin{array}{c}\text { Members of our supply chain use Just in Time } \\
\text { concept / as a tool for enhancing } \\
\text { competitiveness }\end{array}$ & 3.5 & 1.14756 & 3.8 & 0.82955 \\
\hline $\begin{array}{c}\text { Members of our supply chain formally } \\
\text { exchange production information on a regular } \\
\text { basis, eg. through sales and operations planning } \\
\text { meetings }\end{array}$ & 3.5 & 1.06594 & 3.8 & 0.90349 \\
\hline $\begin{array}{c}\text { Members of our supply chain use } \\
\text { benchmarking and performance metrics }\end{array}$ & 3.0 & 1.05972 & 3.6 & 0.55628 \\
\hline $\begin{array}{l}\text { Members of our supply chain have a } \\
\text { standardized quality policy for both products } \\
\text { and processes with established guidelines }\end{array}$ & 3.6 & 1.00011 & 3.6 & 0.44402 \\
\hline $\begin{array}{l}\text { Members of our supply chain have aligned their } \\
\text { product strategies, supply, distribution making } \\
\text { to supply chain strategy }\end{array}$ & 3.6 & 1.03285 & 3.8 & 0.67388 \\
\hline $\begin{array}{c}\text { Member of our supply chain formally share } \\
\text { information about customer requirements and } \\
\text { design plans }\end{array}$ & 3.5 & 0.90101 & 4.3 & 0.59722 \\
\hline $\begin{array}{l}\text { Members of our supply chain use the supply } \\
\text { chain concept to design products, processes and } \\
\text { packaging }\end{array}$ & 3.3 & 0.99849 & 4.4 & 0.95176 \\
\hline $\begin{array}{l}\text { Our supply chain has procedures to provide } \\
\text { feedback from the customer that is involved in } \\
\text { product development }\end{array}$ & 3.5 & 1.04291 & 3.6 & 1.07496 \\
\hline $\begin{array}{l}\text { Members of our supply chain use sustainability } \\
\text { concepts in the supply chain strategy }\end{array}$ & 3.4 & 0.94091 & 3.7 & 0.94440 \\
\hline
\end{tabular}

Source: own compilation

Table 9. The Functioning of the Enterprises within the Supply Chain

\section{Way of functioning within SCM}

Lower logistics costs: An ability to receive lower total logistics costs through effective collaboration in the supply chain and increased activities efficiency

Lower total costs of products: Product competitiveness due to lower total unit cost
Average grade (1=definitely worse than competitors, $2=$ worse than competitors, $3=$ comparable to the competition, $4=$ =better than competitors, $5=$ definitely better than competitors)

Poland St. dev. $\quad$ Romania $\quad$ St. dev.
3.5
0.75189
3.4
0.74915

$\begin{array}{llll}3.7 & 0.79014 & 3.8 & 0.63413\end{array}$


RECENT ISSUES IN ECONOMIC DEVELOPMENT

\begin{tabular}{|c|c|c|c|c|}
\hline $\begin{array}{c}\text { Shortened lead time: An ability to reduce lead } \\
\text { time from receipt of order to delivery to the } \\
\text { customer }\end{array}$ & 3.8 & 0.80632 & 3.9 & 0.59726 \\
\hline $\begin{array}{l}\text { Shorter delivery time: Ability to adjust the } \\
\text { delivery time to customer requirements }\end{array}$ & 3.9 & 0.83115 & 4.1 & 0.96239 \\
\hline $\begin{array}{l}\text { Inappropriate quantity and on time: An ability } \\
\text { to meet specified or scheduled delivery times } \\
\text { and ordered quantities of products }\end{array}$ & 3.8 & 0.81017 & 3.7 & 0.85756 \\
\hline $\begin{array}{c}\text { Higher inventory turnover ratio: value ratio of } \\
\text { sold goods to the average value of inventory } \\
\text { over a given time }\end{array}$ & 3.5 & 0.71231 & 4.3 & 0.69450 \\
\hline $\begin{array}{l}\text { Greater customer satisfaction: the extent to } \\
\text { which the perceived performance of the } \\
\text { business corresponds with customers' } \\
\text { expectations }\end{array}$ & 4.0 & 0.72689 & 4.1 & 0.82033 \\
\hline $\begin{array}{l}\text { Higher market share: the share of the company } \\
\text { in the whole market on which it operates }\end{array}$ & 3.6 & 0.85809 & 4.1 & 0.70351 \\
\hline
\end{tabular}

Source: own compilation

Romanian companies have rated higher in their performance outcomes in relation to the competition; it is seen that not only in inventory turnover rates but also in delivery time, customer satisfaction level and higher market share. Polish companies perceive themselves rather in the category of results level comparable to their competition, only in case of the level of customer satisfaction, they more often assess themselves better.

An essential element of modern supply chain management is also the element of sustainable development based on environmental factors (Table 10).

Table 10. Elements of the Sustainable Development in Supply Chain Management

\begin{tabular}{|c|c|c|c|c|}
\hline \multirow[t]{2}{*}{ Environmental elements } & \multicolumn{4}{|c|}{$\begin{array}{c}\text { Average grade (where } 1=\text { doesn't matter, } \\
2=\text { unimportant, } 3=\text { neutral, } 4=\text { important, } \\
5=\text { very important })\end{array}$} \\
\hline & Poland & St. dev. & Romania & St. dev. \\
\hline Environmentally-friendly production processes & 3.8 & 0.97497 & 4.0 & 0.46078 \\
\hline $\begin{array}{l}\text { Acting towards a reduction in the amount of } \\
\text { waste }\end{array}$ & 4.0 & 0.92504 & 4.3 & 0.49067 \\
\hline $\begin{array}{l}\text { Engaging in production processes free from } \\
\text { harmful substances emissions }\end{array}$ & 4.0 & 0.89647 & 4.6 & 0.61491 \\
\hline Use of renewable sources in the production & 3.7 & 1.08036 & 4.2 & 0.46473 \\
\hline Reuse of materials & 3.9 & 1.12913 & 4.7 & 0.63516 \\
\hline Recycling of defective and waste products & 3.7 & 1.03648 & 4.5 & 0.75282 \\
\hline $\begin{array}{l}\text { Choosing partners in the supply chain on the } \\
\text { basis of environmental guidelines }\end{array}$ & 3.6 & 1.00529 & 4.1 & 0.66597 \\
\hline $\begin{array}{l}\text { Involving workers in environment protection } \\
\text { schemes }\end{array}$ & 3.6 & 0.97645 & 4.3 & 0.44004 \\
\hline
\end{tabular}

Source: own compilation

The average level of evaluation has shown that the environment surrounding impact on the way of the management of the supply chain is greater in the case of Romanian companies. Romanian companies have rated several environmental elements as important and even significant, especially in the reuse or recycling materials. Polish companies are more skeptical on environmental factors and tend to perceive them as indifferent. According to those companies, avoiding harmful emissions of waste and the process of eco-friendly productions are important. 
As an essential aspect of contemporary Supply Chain Management, elements of sustainable development are also indicated based on social factors (Table 11).

Table 11. Social Elements of the Sustainable Development in SCM

\begin{tabular}{|c|c|c|c|c|}
\hline \multirow[t]{2}{*}{ Social Elements } & \multicolumn{4}{|c|}{$\begin{array}{l}\text { Average Grade (where } 1=\text { doesn't matter, } \\
2=\text { unimportant, } 3=\text { neutral, } 4=\text { important, } \\
5=\text { very important) }\end{array}$} \\
\hline & Poland & St. dev. & Romania & St. dev. \\
\hline $\begin{array}{l}\text { Applying the code of ethical conduct } \\
\text { to employees and contractors }\end{array}$ & 4.3 & 0.82401 & 4.3 & 0.48633 \\
\hline $\begin{array}{l}\text { Applying fair employment practices to } \\
\text { the local community }\end{array}$ & 4.4 & 0.73233 & 4.6 & 0.49342 \\
\hline $\begin{array}{l}\text { Providing health and safety } \\
\text { equipment }\end{array}$ & 4.6 & 0.54394 & 4.4 & 0.45872 \\
\hline $\begin{array}{c}\text { Investments in infrastructural } \\
\text { facilities }\end{array}$ & 4.0 & 0.83438 & 4.7 & 0.68583 \\
\hline $\begin{array}{c}\text { Timely and lawful payment of } \\
\text { taxes and fees payable }\end{array}$ & 4.6 & 0.65809 & 4.3 & 0.49915 \\
\hline Clearance of taxable income & 4.6 & 0.68177 & 4.6 & 0.66597 \\
\hline $\begin{array}{l}\text { Applying ethical business and trade } \\
\text { standards }\end{array}$ & 4.4 & 0.65668 & 4.3 & 0.50118 \\
\hline $\begin{array}{c}\text { Investments in poverty reduction } \\
\text { programs }\end{array}$ & 3.5 & 0.87398 & 4.5 & 0.69408 \\
\hline $\begin{array}{l}\text { Contribution in local community } \\
\text { charitable donations }\end{array}$ & 3.5 & 1.00977 & 4.4 & 1.02188 \\
\hline $\begin{array}{l}\text { Contribution in regional and } \\
\text { supraregional development initiatives }\end{array}$ & 3.5 & 1.00477 & 3.9 & 0.66427 \\
\hline
\end{tabular}

Source: own compilation

In this category, the overall positive impact of social factors on SCM is observed in both Polish and Romanian companies, where they are assessed averagely as necessary. At the same time, Polish companies are less likely to act for poverty or regional development, but they actively support possession of the equipment ensuring hygiene and safety at work, timely and lawful payment of taxes and fees payable and transparency of income. Romanian entities agree with the latter, who also consider as essential to invest in infrastructure and apply fair employment practices to the local community. Analysis of main components is based on the data received from the Polish and Romanian SMEs sector. Further, studies are started by determining the adequacy of selection of the K-M-O sample, which allows determining whether the principal components can be analyzed. The K-M-O measure value of over 0.5 allows isolating the main components. According to the Varimax Rotation Method with Kaiser Normalization, the values of the factors are determined. The results of each area are shown in Table 12. 
Table 12. K-M-O Measure and Number of Variables and Components for Several SCM Areas

\begin{tabular}{lccc}
\hline \multicolumn{1}{c}{ SCM area } & K-M-O measure & $\begin{array}{c}\text { Number of dependent } \\
\text { variables }\end{array}$ & $\begin{array}{c}\text { Number of } \\
\text { established factors }\end{array}$ \\
\hline SCM determinants & 0.663 & 7 & 3 \\
\hline $\begin{array}{l}\text { Factors supporting } \\
\text { SM }\end{array}$ & 0.678 & 7 & 3 \\
\hline $\begin{array}{l}\text { Barriers in } \\
\text { implementing SCM }\end{array}$ & 0.737 & 7 & 2 \\
\hline Sort of practices & 0.841 & 13 & 4 \\
\hline Way of functioning & 0.777 & 8 & 2 \\
\hline Environmental & 0.849 & 8 & 2 \\
\hline Social elements & 0.748 & 10 & 3 \\
\hline TOTAL & - & 60 & 19 \\
\hline Source: & & &
\end{tabular}

Source: own compilation

\section{Results}

The analysis of the main components of the seven areas of SCM allows a significant reduction in the number of variables to the level of a dozen or so significant factors that are supposed to explain the variance of the results for the whole studied phenomenon. Preliminary observations indicate that the main reasons for implementation of SCM are the desire to increase the efficiency of processes and to meet the needs of the end customer; the latter is also a key factor supporting the implementation of SCM. Simultaneously, the most significant barriers are the formal and communicative constraints and the reluctance of employees to accept the changes. Implemented practices in the exchange of information and the formalization and standardization of activities result in a high level of customer service and thus, higher sales are noted than the competitors. Both the recycling of waste and the use of pro-environmental technologies play an important role in sustainable development. Ethical behavior towards local society is also a vitalpoint.

\section{Discussions}

The state of SCM implementation in Romanian companies as observed by C. Vasiliu, and M. Dobrea (2013) using over 225 samples and by Diana M.D. and Cristina A. (2014), study over the strengths and weaknesses, gives the same conclusion as mentioned earlier.

Considering the IT environment and the implementation of ERP systems, studies have shown that around 2015, Romania has a mid-level grade, thus urging further development and better integration to achieve international levels of development in this field. New opportunities arise in the form of Cloud-based implementation and big-data optimization routines (Oracle study based on a survey conducted by IDG Connect (2016).In the logistics domain of SCM, O. Kherbach and M. L. Mocan (2016) consider that in order to connect the Romanian economy to the world trends and processes, the highest priority should be given to the improvement of logistics and SCM in Romania, SMEs with well-organized logistics and SCM. From the SCM strategy point of view, R. Wright (2013) considers that the factors determining supply chain strategy for manufacturing companies in Romania are aligned based on the type of product. A new approach for SCM resilience in Romanian companies, by V. Popa (2013), shows that reverse factoring does not solve all liquidity issues when credit is stretched. 


\section{Conclusion}

Polish companies pay more attention to customers' needs, while Romanian companies are driven by internal conditions in the supply chain. Romanian companies are more concerned on the barriers to the SCM implementation, at the same time they perceive themselves better in the field of performance outcomes in relation to the competitors. They seriously consider environmental elements important in SCM sustainable development. For Polish companies, the priority is to follow the law and external procedures.

Previous research for SCM in SME targeting Romanian and Polish companies have focused primarily on the association between product diversity and topology of the supply chain. SCM is achieved through partnerships with 3PL suppliers/transporters and customers, from the previous studies conducted in this area; this issue is resolved through the expansion of upstream and downstream of companies' activities. Data analysis and interpretation over logistics services market in Romania indicate its growth in the last decade, considering the construction of logistics parks that provide multiple facilities and the increase of quality in transport operations through the proper endowment of the industry. The economic crisis determines the stagnation in the development projects of logistics parks. In terms of SCM, Romanian companies and their managers give a medium importance to this process; it is evident from the studies cited in the research.

The survey questionnaire used in this study is evaluated the SCM concept in SMEs measuring the average level in the evaluation of factors concerning different SCM areas. The purpose of the research is to assess the SCM concept in SMEs of Romania and Poland, more specifically the identification of similarities and differences in the approach to SCM concept. The sample size (211 SMEs)is identical for each surveyed country, and the sample structure is chosen randomly. Although the statistical models used in this study appear robust, there are limitations regarding the number and choice of industries (more industries may need to be represented in the sample) and size of companies (the sample represents a wide range of sizes). Yet, a systematic approach is used; still, there is a difficulty to evaluate all aspects based on tertiary data. Future research could benefit by deeper understanding and investigating the present results of this study.

\section{References}

Abrhám, J., Bilan, Y., Krauchenia, A., \& Strielkowski, W. (2015). Planning horizon in labour supply of Belarusian small entrepreneurs. Economic research-Ekonomska istraživanja, 28(1), 773787. https://doi.org/10.1080/1331677X.2015.1084238

Ahmad, I., Oláh, J., Popp, J., \& Máté, D. (2018). Does business group affiliation matter for superior performance? Evidence from Pakistan. Sustainability, 10 (9), art. no. 3060, DOI: $10.3390 / \mathrm{su} 10093060$

Androniceanu, A. (2017). The three-dimensional approach of Total Quality Management, an essential strategic option for business excellence. Amfiteatru Economic, 19(44), 61-78.

Arend, R. J., \& Wisner, J. D. (2005). Small business and supply chain management: is there a fit?. Journal of Business Venturing, 20, 403-436, https://doi.org/10.1016/j.jbusvent.2003.11.003

Diaconu, D. M., \& Alpopi, C. (2014). Strengths and weaknesses of current Supply Chain Management and initiatives for the future, Proceedings of the 8th International Management Conference "Management Challenges for Sustainable Development", November 6th-7th, Bucharest, Romania, 1165-1172.

Dolado, J. J., \& Lütkepohl, H. (1996). Making Wald Test Work for Cointegrated VAR Systems. Econometric Reviews, 15, 369-386.

Dumitrascu, O., \& Hila, C. M. (2017). Actual state of knowledge in the field of Supply Chain Management, 8th International Conference on Manufacturing Science and Education - MSE 
2017 "Trends in New Industrial Revolution", MATEC Web of Conferences 121, https://doi.org/10.1051/matecconf/201712107007.

Ehrenberger, M., Koudelkova, P., \& Strielkowski, W. (2015). Factors influencing innovation in small and medium enterprises in the Czech Republic. Periodica Polytechnica Social and Management Sciences, 23(2), 73-83. https://doi.org/10.3311/PPso.7737

Ghicajanu, M. (2014). Open Innovation - A Solution In The Redesigning Of Supplying Chain Management. Case Study In Innovation Networks From Procter \& Gamble. Supply Chain Management Journal, 5(2), Targoviste, 39-48.

INNSE. (2009). Monthly Statical Bulletin. Retrieved April, 2009 from http://www.insse.ro/cms/files/arhiva_buletine2009/bsl_4.pdf.

Kherbach, O., \& Mocan, M. L. (2015). The importance of logistics and Supply Chain Management in the Enhancement of Romanian SMEs, SIM 2015 / 13th International Symposium in Management, [in:] Procedia - Social and Behavioral Sciences, 221, 405 - 413.

Kherbach, O., \& Mocan, M. L. (2016). Overview of Information Technology and a Theoretical Model in Supply Chain Management for local SMEs. SEA - Practical Applications of Science, IV, 3(12), 527-537.

Kisperska-Moroń, D., Klosa, E., Świerczek, A. \& Liniecki, R. (2010). Funkcjonowanie małych $i$ średnich firm produkcyjnych $w$ tańcuchu dostaw, Wyd. Uniwersytetu Ekonomicznego in Katowice, Katowice.

Kljucnikov, A., Belas, J., Kozubikova, L. \& Pasekova, P. (2016). The Entrepreneurial Perception of SME Business Environment Quality in the Czech Republic. Journal of Competitiveness, 8(1), 66-78, DOI: 10.7441/joc.2016.01.05.

Korcsmáros, E., \& Šimova, M. (2018). Factors affecting the business environment of SMEs in Nitra region in Slovakia. Oeconomia Copernicana, 9(2), 309-331. https://doi.org/10.24136/oc.2018.016.

Kot, S. (2018). Sustainable supply chain management in small and medium enterprises. Sustainability, 10 (4), art. no. 1143 . DOI: 10.3390/su10041143

Kovács, G.\& Kot, S. (2016). New logistics and production trends as the effect of global economy changes. Polish Journal of Management Studies, 14(2), 115-126, DOI: 10.17512/pjms.2016.14.2.11

Kozma, T. (2017). Cooperation in the supply chain network. Forum Scientiae Oeconomia, 5(3), 45-58.

Kozubikova, L., Homolka, L. \& Kristalas, D. (2017). The Effect of Business Environment and Entrepreneurs' Gender on Perception of Financial Risk in the SMSs Sector. Journal of Competitiveness, 9(1), 36-50, DOI: 10.7441/joc.2017.01.03.

Liberko, I., Bednarová, L., Hajduová, Z. \&Chovancová, J. (2015). Possibilities to optimize the logistics chain in the manufacturing plant. Polish Journal of Management Studies, 12 (2), 103 113.

Lütkepohl, H., \& Kratzig, M. (2004). Applied Time Series Econometrics (Themes in Modern Econometrics). Cambridge University Press.

Nze, I., \& Onyemechi, C. (2018). Port congestion determinants and impacts on logistics and supply chain network of five African ports. Journal of Sustainable Development of Transport and Logistics, 3(1), 70-82. doi:10.14254/jsdt1.2018.3-1.7

OECD (2009). Top barriers and drivers to SME internationalisation. Report by the OECD Working Party on SMEs and Entrepreneurship, OECD.

Oláh, J., Karmazin, Gy., Máté, D., Grabara, J. K., \& Popp, J. (2017). The effect of acquisition moves on income, pre-tax profits and future strategy of logistics firms. Journal of International Studies, 10(4), 233-245. doi:10.14254/2071-8330.2017/10-4/18.

Onwuegbuchunam, D., Okeke, K., Igboanusi, C., \& Ugboma, O. (2018). Structural changes in the global transport chain: Implications for ports. Journal of Sustainable Development of Transport and Logistics, 3(1), 22-28. doi:10.14254/jsdtl.2018.3-1.2

Oracle. (2016). Retrieved from http://www.oracle.com/us/products/applications/idg-connect-reportinfographic-3101243.pdf. 
Popa, V. (2013, February). The Financial Supply Chain Management: a New Solution for Supply Chain Resilience. Amfiteatru Economic, XV(33), 140-153.

Shpak, N., Satalkina, L., Sroka, W. \&Hittmar S. (2017). The social direction of enterprises' innovation activity. Polish Journal of Management Studies, 16(1), 187-201, DOI: 10.17512/pjms.2017.16.1.16

Strielkowski, W., \& Čábelková, I. (2015). Religion, culture, and tax evasion: Evidence from the Czech Republic. Religions, 6(2), 657-669. https://doi.org/10.3390/rel6020657

Szczepańska-Woszczyna, K. (2014). The importance of organizational culture for innovation in the company. Forum Scientiae Oeconomia, 2(3), 27-39.

Ţarţavulea, R. I., \& Petrariu, R. I. (2013, February). Logistics Market Statistics and Opinions about the Supply Chain Management in Romania. Amfiteatru Economic, XV(33), 44-55.

Thakkar, J., Kanda, A. \& Deshmukh, S. G. (2011). Mapping of supply chain learning: a framework for SMEs. The Learning Organization, 18, 313- 332.

Thakkar, J., Kanda, A. \& Deshmukh, S. G. (2008). Supply chain management in SMEs: development of constructs and propositions. Asia Pacific Journal of Marketing and Logistics, 20, 97-131.

Tvaronavičienè, M., Razminienè, K. \& Piccinetti, L. (2015). Approaches towards cluster analysis. Economics and Sociology, 8 (1), 19-27.

Vasiliu, C. \& Dobrea, M. (2013, February). State of implementation of Supply Chain Management in companies in Romania, Amfiteatru Economic, XV(33),180-196.

Wright, R. (2013). Supply Chain Strategies of Manufacturers in Romania. International Journal of Applied Management Science, 5(1), 80-99.

Zimon, D. (2017). The influence of quality management systems for improvement of logistics supply in Poland. Oeconomia Copernicana, 8(4), 643-655. https://doi.org/10.24136/oc.v8i4.39.

Zowada, K. (2011). Logistyczne aspekty funkcjonowania małych i średnich przedsiębiorstw [in:] A. Adamik (ed.) Kształtowanie konkurencyjności i przewagi konkurencyjnej małych i średnich przedsiębiorstw, C.H. Beck, Warszawa, 160-169.

Zygmunt, J. (2018). Entrepreneurial activity drivers in the transition economies. Evidence from the Visegrad countries. Equilibrium. Quarterly Journal of Economics and Economic Policy, 13(1), 89-103. https://doi.org/10.24136/eq.2018.005. 